\title{
Senario Masalah Pelajar Universiti Utara Malaysia
}

\author{
NAJIB AHMAD MARZUKI \\ CHE SU MUSTAFFA \\ ZARINA MAT SAAD \\ SUHANIM ABDULLAH
}

\begin{abstract}
Students of higher learning institutions inevitably face many problems during their studies. The problems faced are academic stress, time management, adjustment, teaching method, student-lecturer communication, learning environment and heavy workload. Students' self-esteem and parenting styles also contributed towards such problems. The aims of this study were to identify the contributing factors based on several demographic components, to examine the relations among the factors and to propose some suggestions to help students deal with the problems. A cross-sectional survey was employed and data were collected using questionnaire. A total of 1923 respondents were chosen to participate in the study through stratified-random sampling. Results indicated that adjustment was the most dominant factor among male and female students. Among the most dominant factors based on ethnicity were adjustment, self-esteem, time management, student-lecturer communication and teaching method. There were relationships between academic stress and other factors such as time management, students'workload, parenting styles, and self-esteem. In addition, adjustment was found to have relationships with time management, self-esteem, learning environment, parenting styles, teaching method, studentlecturer communication and workload. Results also showed female students having a higher level of academic stress compared to their male counterparts. Malay students also had a higher level of academic stress than other ethnic groups. In term of academic discipline, there were significant differences in four factors which were academic stress, workload, learning environment, and parenting styles.
\end{abstract}

\begin{abstract}
ABSTRAK
Pelajar-pelajar di institusi pengajian tinggi(IPT) terpaksa berhadapan dengan pelbagai masalah semasa menuntut di IPT. Masalah-masalah yang dihadapi termasuklah tekanan akademik, pengurusan masa, penyesuaian, pengajaran pensyarah, komunikasi pensyarah-pelajar, persekitaran, beban tugas dan seumpamanya. Masalah ini turut dipengaruhi oleh penghargaan kendiri dan
\end{abstract}


memuaskan seperti mencapai kelulusan Ijazah Kelas Pertama atau Kelas Kedua Atas, berbanding dengan etnik lain. Statistik menunjukkan hanya sebahagian kecil yang boleh mencapai Kelas Pertama dan Kelas Kedua Atas di Universiti Utara Malaysia. Statistik pada konvokesyen Universiti Utara Malaysia tahun 2003 menunjukkan bahawa hanya $26(0.4 \%)$ orang pelajar mendapat Ijazah Kelas Pertama daripada 5,878 pelajar manakala 2,233 $(38 \%)$ orang pelajar mendapat Ijazah Kelas Kedua Atas dan 3,619 (61.6\%) orang mendapat Ijazah Kelas Kedua Bawah. Manakala bagi statistik konvokesyen 2004 pula daripada 5,683 orang graduan ijazah sarjana muda, hanya 73 (1\%) orang telah berjaya mendapat Ijazah Kelas Pertama, 2,218 (39\%) orang Ijazah Kelas Kedua Atas dan 3,392 (60\%) orang mendapat Ijazah Kelas Kedua Bawah.

Antara faktor yang dikenal pasti menyumbang kepada perangkaan ini ialah sikap pelajar seperti soal pengurusan masa, komunikasi antara pensyarahpelajar, penyesuaian pelajar dan faktor tekanan. Faktor lain yang boleh mempengaruhinya termasuklah gaya asuhan ibu bapa, personaliti, beban tugas, aspek-aspek persekitaran serta aspek pengajaran pensyarah. Kemerosotan prestasi akademik di kalangan pelajar meliputi elemen risiko akademik secara umum (Eccles \& Smidgley, 1989). Sikap pelajar terhadap sekolah umpamanya menjadi semakin negatif, penghargaan kendiri dan konsep kendiri akademik pula semakin menurun (Marsh, 1989). Situasi ini menunjukkan tekanan akademik merupakan faktor yang penting kerana memberi implikasi terhadap proses penyesuaian pelajar dan motivasi. Tahap motivasi yang rendah boleh membawa kepada risiko meninggalkan pengajian sebelum waktunya.

Dalam konteks ini, komunikasi guru-pelajar dikatakan turut memainkan peranan yang penting. Guru mengkomunikasikan nilai-nilai berkaitan dengan pembelajaran dan harapan mereka terhadap kejayaan para pelajar secara langsung atau tidak langsung seperti mengklasifikasi, penetapan matlamat dan memberi maklumbalas. Secara tidak langsung, kepelbagaian bentuk hubungan antara pelajar-guru adalah merupakan peramal kepada motivasi dan penyesuaian di sekolah (Murdock, Anderman \& Hodge, 2000). Tahap motivasi yang tinggi di kalangan pelajar dikaitkan dengan keupayaan guru untuk mengetahui, menyokong, mencabar dan menggalakkan pelajar untuk bertindak (Eccles \& Smidgley, 1989). Pelajar-pelajar juga gemar dilayan sebagai 'orang penting' atau diberikan keutamaan. Misalnya, hasil kajian oleh Wentzel (1997) mendapati guru yang dianggap mengambil berat ialah guru-guru yang menunjukkan komitmen terhadap pengajaran, mengenali keperluan dan kekuatan akademik pelajar, dan gaya interaksi yang demokratik. Murdock (1999) turut mendapati bahawa tahap pencapaian pelajar-pelajar yang tinggi mempunyai hubungan dengan tahap di mana mereka menanggapi guru-guru mereka sebagai berlaku adil terhadap mereka di dalam bilik darjah dan meletakkan harapan yang tinggi terhadap pelajar. Dengan itu, hubungan positif antara guru-pelajar tidak hanya dicirikan oleh hubungan baik, tetapi komunikasi yang jelas bahawa nilai yang 
gaya asuhan ibubapa. Sehubungan itu, kajian ini dijalankan bertujuan untuk mengenalpasti faktor-faktor berkenaan mengikut aspek demografi, mengenal pasti hubungan antara faktor-faktor tersebut serta mengemukakan cadangan bagi membantu para pelajar di IPT. Kajian ini merupakan kajian lapangan keratan rentas yang menggunakan soal selidik sebagai alat pengumpulan data. Sejumlah 1923 orang responden terlibat dalam kajian ini. Teknik persampelan yang digunakan ialah persampelan rawak berstratifikasi. Hasil kajian menunjukkan faktor penyesuaian merupakan faktor yang paling dominan di kalangan pelajar lelaki dan perempuan. Dari segi bangsa, faktor-faktor yang paling dominan ialah penyesuaian, penghargaan kendiri, pengurusan masa, komunikasi pensyarah-pelajar dan pengajaran pensyarah. Hasil analisis menunjukkan faktor pengurusan masa, beban tugas, gaya asuhan dan penghargaan kendiri mempunyai hubungan dengan faktor berkenaan. Faktor penyesuaian pula mempunyai hubungan dengan pengurusan masa, penghargaan kendiri, persekitaran, gaya asuhan, pengajaran pensyarah, komunikasi pensyarah-pelajar dan beban tugas. Di samping itu, hasil analisis menunjukkan pelajar perempuan mengalami tekanan akademik yang lebih ting gi berbanding pelajar lelaki. Pelajar Melayu mengalami tekanan akademik yang lebih tinggi berbanding pelajar bangsa lain. Dari segi jurusan pengajian, terdapat perbezaan yang signifikan dalam empat faktor iaitu tekanan akademik, beban tugas, persekitaran, beban tugas dan gaya asuhan.

\section{PENGENALAN}

Pelajar-pelajar yang berjaya menjejakkan kaki ke peringkat universiti boleh dianggap telah matang dalam aspek pembelajaran bagi membolehkan mereka berdikari dan menyesuaikan diri dengan persekitaran dan suasana pembelajaran di universiti. Namun begitu, persekitaran universiti turut memberikan cabaran kepada pelajar-pelajar ini apabila terpaksa berdepan dengan pelbagai masalah (Othman, 2001). Masalah ini meliputi masalah tekanan akademik, pengurusan masa, penyesuaian, pengajaran pensyarah, persekitaran, beban tugas dan komunikasi pelajar-pensyarah. Manakala faktor lain yang boleh mempengaruhi ialah penghargaan kendiri pelajar dan gaya asuhan yang diterima. Masalah ini harus ditangani secara bijak oleh para pelajar di universiti bagi membolehkan mereka mengharungi kehidupan di kampus dengan jayanya.

Walaupun universiti menyediakan pelbagai kemudahan bagi membantu pelajar menghadapi masalah ketika berada di kampus, latar belakang demografi yang pelbagai telah menyebabkan berlakunya variasi dalam permasalahan yang dihadapi oleh mereka (Michie, Glachan \& Bray, 2001). Contohnya ada pelajar yang cemerlang dalam bidang akademik tetapi mempunyai masalah dari segi pengurusan masa, dan penyesuaian. Pencapaian pelajar-pelajar di universiti terutamanya pelajar-pelajar Melayu tidak menunjukkan prestasi yang 
peperiksaan, belajar untuk menghadapi peperiksaan, terlalu banyak tugasan untuk dikerjakan, kehendak diri untuk mencapai keputusan yang cemerlang serta membuat esei atau projek merupakan punca tekanan yang paling utama di kalangan pelajar. Ini menunjukkan aktiviti berkait dengan akademik adalah punca tekanan utama pelajar. Kajian ini turut mendapati bahawa responden perempuan melaporkan tahap tekanan akademik yang lebih tinggi berbanding responden lelaki. Kajian juga mendapati responden dengan kepercayaan kawalan luaran melaporkan tahap tekanan yang lebih tinggi berbanding responden dengan kepercayaan kawalan dalaman. Responden yang mempunyai harga diri yang lebih tinggi melaporkan tekanan akademik yang lebih rendah. Pengkaji membuat kesimpulan bahawa personaliti merupakan faktor penting dalam tindak balas seseorang terhadap tekanan.

Dalam satu kajian berasingan menggunakan instrumen ASQ yang sama, Michie, Glachan dan Bray (2001) mengkaji faktor yang mempengaruhi konsep kendiri akademik, penghargaan kendiri, dan tekanan akademik di kalangan pelajar-pelajar universiti. Hajian kajian mendapati bahawa tekanan akademik yang tinggi mempunyai hubungan negatif yang signifikan dengan konsep kendiri akademik, harga diri, penilaian rakan sebaya terhadap keupayaan akademik diri, keyakinan diri dalam keupayaan akademik, kepuasan terhadap universiti, tabiat belajar yang baik dan niat memasuki universiti sebagai ransangan sosial. Ranjita dan Mckean (2000) mendapati pengurusan masa memberi kesan 'buffer' yang lebih besar terhadap tekanan akademik berbanding dengan penglibatan aktiviti riadah. Responden perempuan melaporkan tingkah laku pengurusan masa yang lebih berkesan berbanding responden lelaki. Walau bagaimanapun responden perempuan turut melaporkan kadar tekanan yang lebih tinggi. Ranjita dan Mckean merumuskan pengurusan masa sebagai strategi berkesan untuk mengurangkan tekanan akademik di kalangan pelajar universiti.

Macan (1994) mengkaji pengurusan masa di kalangan pelajar-pelajar universiti berbanding dengan prestasi akademik dan tekanan dalam pembelajaran. Beliau telah membentuk satu instrumen yang dikenali sebagai Time Management Behavior (TMB), dan kajian telah dilakukan ke atas 165 orang pelajar universiti. Hasil kajian mendapati responden yang mencatatkan tahap TMB yang lebih baik dapat memainkan peranan diri yang lebih jelas, kurang ketegangan somatik, kepuasan kerja dan kepuasan hidup yang lebih tinggi serta prestasi kerja yang lebih baik. Ini bermakna responden yang dapat menguruskan masa mereka dengan lebih berkesan akan melaporkan tahap tekanan yang lebih rendah dan melaporkan pencapaian akademik yang lebih baik. Responden perempuan pula menunjukkan pengurusan masa yang lebih baik berbanding responden lelaki. Walau bagaimanapun, Macan merumuskan bahawa terdapat dimensi atau facet dalam pengurusan masa yang lebih kompleks daripada yang dijangkakan.

Bidin, Sharifah Soa'ad, Mohd Sobri dan Zurni (1995) mendapati sistem 
tinggi diletakkan kepada pembelajaran dan kejayaan pelajar. Guru dan pensyarah dalam konteks ini memainkan peranan penting dalam mewujudkan suasana pembelajaran yang sesuai.

Menurut Huang (Suradi, 1984), faktor seperti persaingan akademik dan sosial, serta perpisahan daripada sokongan keluarga boleh mendatangkan tekanan dan keresahan dalam kehidupan universiti. Ini bermakna pelajar-pelajar terpaksa berdepan dengan suatu perubahan baru dalam kehidupan mereka. Jika mereka tidak dapat menyesuaikan diri dengan baik, terdapat kemungkinan kesan negatif terhadap pembelajaran mereka di universiti akan timbul. Pada masa yang sama, penguasaan bahasa turut menyumbang kepada masalah di kalangan pelajar, terutamanya masalah Bahasa Inggeris. Dalam konteks ini, keupayaan berbahasa dirujuk sebagai persepsi kendiri dan keupayaan sebenar untuk bercakap dan memahami (dalam persekitaran akademik dan sosial) serta membaca dan menulis di dalam Bahasa Inggeris akademik. Ini kerana kebanyakan bahan rujukan adalah dalam Bahasa Inggeris.

Selain itu, faktor asuhan dan galakan yang diterima oleh keluarga turut memainkan peranan penting. Handsford dan Hattie, Sharelson dan Bacus, serta Eshel dan Karman (Othman, 2001), mencadangkan bahawa faktor latar belakang seperti persekitaran keluarga, taraf sosio-ekonomi keluarga dan kecerdasan boleh mempengaruhi konsep kendiri seseorang. Ahli keluarga terutamanya ibu bapa merupakan agen sosialisasi terpenting bagi anak-anak. Sebagai ketua keluarga,ibu bapa merupakan pembentuk bagi persekitaran keluarga dan mereka adalah model terbaik bagi anak-anak.

Berdasarkan senario yang dibincangkan, artikel ini membicarakan sebahagian dapatan utama kajian yang dilakukan untuk mengenalpasti tahap masalah yang dihadapi oleh pelajar-pelajar di Universiti Utara Malaysia. Permasalahan yang dikaji ialah tekanan akademik, pengurusan masa, komunikasi pelajarpensyarah, beban tugas akademik, persekitaran kampus, pengajaran pensyarah dan persekitaran. Selain itu, kajian ini juga dilakukan untuk mengenalpasti dua faktor lain iaitu penghargaan kendiri dan gaya asuhan keluarga yang dianggap memainkan peranan penting dalam masalah yang dihadapi oleh pelajar-pelajar di Universiti Utara Malaysia.

\section{TINJAUAN LITERATUR}

Abouserie (1994) mengkaji tekanan akademik 675 orang pelajar tahun dua dari sembilan jabatan di University of Wales, College of Cardiff. Berdasarkan instrumen Academic Stress Questionnaire (ASQ), beliau cuba mengenalpasti punca tekanan akademik dan perkaitan di antara tekanan akademik pelajar dengan faktor jantina, tahap tekanan, kawalan lokus dan penghargaan kendiri pelajar. Hasil kajian menunjukkan bahawa peperiksaan dan keputusan 
tinggi dan konsep kendiri yang paling negatif di antara tiga kategori gaya asuhan tersebut.

Perbezaan individu dalam penghargaan kendiri mempunyai kesan ke atas kesihatan mental, tingkahlaku interpersonal dan keceriaan psikologikal. Okun dan Fournett (1991) mendapati pelajar-pelajar universiti yang mempunyai penghargaan kendiri yang rendah mempunyai reaksi emosi dan kognitif yang rendah terhadap aktiviti universiti. Ini bertepatan dengan pandangan Lecky (Michie, Glachan \& Bray, 2001) yang menyatakan pentingnya penghargaan kendiri dalam mengharungi kehidupan di kampus. Pelajar yang rendah penghargaan kendiri, tetapi mendapat gred yang tinggi juga kemungkinan tidak berupaya mengekalkan kecermerlangan mereka. Nouwens (1997) pula berpendapat, apabila pensyarah membebankan pelajar dengan begitu banyak maklumat pada satu-satu masa, ia bukanlah satu teknik pengajaran yang tepat. Pensyarah sepatutnya menggalakkan pelajar mendapatkan maklumat tambahan sama ada daripada perpustakaan atau internet. Jika pelajar dibebani dengan bahan bacaan yang terlalu banyak, mereka akan berkecenderungan untuk menggunakan kaedah pembelajaran "luaran" (iaitu bersifat mencari fakta). Biasanya kaedah pembelajaran begini adalah berkesan untuk jangka waktu pendek sahaja. Oleh itu, beliau berpendapat untuk permulaan semester, pelajar haruslah diberi beban tugas dan tahap kesusahan pembelajaran yang bersifat ringan atau rendah dahulu. Kemudian, tahap kesusahan dan beban tugas pelajar akan ditingkatkan sedikit demi sedikit sehinggalah ke penghujung semester. Dengan cara ini, pensyarah dapat memberi masa kepada pelajar untuk membina keyakinan terhadap kursus atau subjek yang dipelajari dan mereka mampu mendapatkan maklumat selanjutnya dengan lebih berkesan. Pramsden (Burnett, 2000), mengkaji pengaruh persekitaran pembelajaran seperti yang dipersepsikan oleh pelajar-pelajar dengan pendekatan pembelajaran. Mereka melaporkan terdapat hubungan antara pendekatan dan strategi pencapaian dengan sokongan pengajaran dan persediaan untuk pendidikan tinggi. Dart, Burnett, Bouilton-Lewis, Campbell dan Smith (Burnett, 2000) mendapati bahawa pendekatan mendalam (deep approach) berkaitan dengan persekitaran pembelajaran dipersepsikan sebagai mempunyai tahap personalisasi yang tinggi (amat berkaitan dengan diri pelajar), penglibatan dan kemahiran pembelajaran yang bercorak investigative.

Pengalaman pengajaran-pembelajaran di sekolah dan universiti adalah berbeza. Menurut T. Subahan (1990), penyelidikan perlu dilakukan untuk mengenalpasti perbezaan proses pengajaran di kedua-dua buah institusi tersebut supaya ia dapat membantu para pelajar. Sekiranya tiada sebarang tindakan diambil berkemungkinan pelajar-pelajar yang memasuki universiti akan mengalami masalah pembelajaran atau tidak mampu menghabiskan tempoh pengajian. Untuk mengenal pasti tingkahlaku guru/pensyarah dan persepsi 
perkuliahan di universiti turut menyumbang kepada kurangnya interaksi pelajarpelajar, dan ini menyebabkan pelajar lemah semakin bermasalah dan semakin terabai. Di sekolah, perhatian berterusan diberikan oleh guru semasa dalam kelas dan sebarang masalah yang timbul diselesaikan atas inisiatif pelajar. Manakala di universiti mereka perlu berusaha bertemu dengan pensyarah bagi menyelesaikan masalah mereka. Perkara ini disedari oleh kebanyakan pensyarah, tetapi ia tidak mampu dilaksanakan kerana bilangan pelajar yang terlalu ramai dan tidak bersesuaian dengan keadaan pembelajaran di peringkat tinggi. Lantaran tidak dapat menyesuaikan diri dengan budaya pembelajaran di universiti, mereka tidak dapat menghargai peranan pensyarah dalam membantu pelajar dan dengan ini pelajar kurang memanfaatkan khidmat pensyarah. Kegagalan tersebut juga menyebabkan pelajar masih mengamalkan budaya pembelajaran secara bersendirian.

Suradi (1984) mengkaji tentang penyesuaian pelajar-pelajar Malaysia yang belajar di Western Michigan University. Berdasarkan instrumen Michigan International Student Problem Inventory (MISPI) yang telah direkabentuk oleh Porter, kajian dilakukan bagi mengenalpasti penyesuaian pelajar dengan beberapa faktor demografi pelajar, keupayaan bahasa Inggeris, sokongan kewangan, pengalaman kerja, pergaulan dengan pelajar tempatan, perkhidmatan keagamaan, tempat tinggal dan penggunaan kaunselor pelajar (Suradi (1984). Hasil kajian mendapati masalah kewangan dan bahasa Inggeris merupakan dua permasalahan utama pelajar-pelajar Malaysia. Pelajar dari luar bandar, pelajar yang gemar berinteraksi dengan pelajar negara sendiri dan kurang berinteraksi dengan pelajar tempatan lebih menghadapi masalah Bahasa Inggeris yang serius.

Gaya asuhan ibu bapa mempunyai perhubungan dengan tahap penyesuaian dan kejayaan akademik pelajar-pelajar universiti. Responden yang menyatakan ibu bapa mereka memberikan autonomi yang lebih tinggi melaporkan tahap penyesuaian dan pencapaian akademik yang lebih baik. Tahap sokongan emosi ibu bapa yang lebih tinggi juga membawa kepada tahap keyakinan, keteguhan (persistence) dan penglibatan dalam kerja. McClun dan Merrell (1998) pula mengkaji hubungan antara tiga jenis gaya asuhan (autoritarian, permisif dan autoritatif), orientasi kawalan dan konsep kendiri di kalangan remaja. Sampel kajian terdiri daripada 198 orang pelajar, berumur antara 13-16 tahun. Daripada sampel itu, terdapat 57 peratus sampel lelaki, dan 43 peratus sampel perempuan. Dapatan kajian menunjukkan lapan peratus daripada pelajar mempunyai ibu bapa permisif, 19 peratus mempunyai ibu bapa autoritarian, dan 73 peratus mempunyai ibu bapa autoritatif. Pelajar yang mempunyai ibu bapa autoritatif mempunyai kawalan dalaman yang lebih tinggi berbanding dua kumpulan lagi. Kajian juga menunjukkan bahawa apabila konsep kendiri semakin menurun, daya kawalan akan menjadi semakin mendalam. Kesimpulannya, para pelajar yang mempunyai ibu bapa autoritarian menunjukkan kawalan luaran yang 


\section{Pecahan Sampel mengikut Fakulti}

Bil Fakulti

1 Fakulti Pembangunan Sosial dan Manusia

2 Fakulti Ekonomi

3 Fakulti Pengurusan

Fakulti Perakaunan

5 Fakulti Teknologi Maklumat

6 Fakulti Pengurusan Pelancongan dan Hospitaliti

7 Fakulti Sains Kognitif dan Pendidikan

8 Fakulti Kewangan dan Perbankan

9 Fakulti Sains Kuantitatif

10 Fakulti Pengajian Antarabangsa

11 Fakulti Pengurusan Awam dan Undang-undang

12 Fakulti Komunikasi dan Bahasa Moden

13 Fakulti Pengurusan Teknologi Jumlah

14 Tidak menyatakan fakulti JUMLAH

\author{
Sampel Sampel \\ Populasi Lelaki Perempuan Jumlah
}

$\begin{array}{cccc}1,678 & 33 & 154 & 187 \\ 1,278 & 33 & 84 & 117 \\ 2,569 & 76 & 202 & 278 \\ 2,288 & 65 & 262 & 327 \\ 1,345 & 14 & 87 & 101 \\ 610 & 10 & 69 & 79 \\ & & & \\ 1,491 & 30 & 115 & 145 \\ 936 & 24 & 76 & 100 \\ 401 & 10 & 30 & 40 \\ 1,598 & 37 & 113 & 150 \\ 1,956 & 67 & 140 & 207 \\ & & & \\ 752 & 16 & 71 & 87 \\ & & & \\ 1,454 & 21 & 79 & 100 \\ 1,454 & 21 & 74 & 95 \\ & & 5 & 5 \\ 18,356 & 436 & 1487 * & 1923^{*}\end{array}$

* termasuk 5 orang responden yang tidak menyatakan program pengajian mereka

\section{Soal Selidik}

Soal selidik bagi kajian ini adalah terdiri daripada soal selidik piawai dan juga soal selidik yang dibentuk sendiri berdasarkan faktor yang dikaji. Soal selidik ini dibahagikan kepada 10 bahagian dengan menggunakan skala tertentu, seperti berikut;

Bahagian A : $\quad$ Mengukur maklumat demografi asas.

Bahagian B : $\quad$ Mengukur faktor tekanan akademik.

Bahagian C : $\quad$ Mengukur faktor pengurusan masa.

Bahagian D : $\quad$ Mengukur faktor penyesuaian.

Bahagian E : $\quad$ Mengukur faktor penghargaan kendiri.

Bahagian F : $\quad$ Mengukur faktor beban tugas.

Bahagian G : $\quad$ Mengukur faktor persekitaran. 
pelajar berdasarkan pengalaman yang dialami oleh pelajar di sekolah dan universiti, beliau membentuk sebuah alat soal selidik. Soal selidik yang dibina oleh heliaw tersebut boleh diterimapakai kerana mempunyai keholehpercayaan yang memuaskan. Hasil daripada penggunaan soal selidik tersebut, beliau mendapati wujud perbezaan di antara tingkahlaku pengajaran di sekolah dan jurition.

\section{OBJEKTIF KAJIAN}

Secara khususnya kajian ini bertujuan untuk:

1. Mengenal pasti dari sudut demografi faktor (tekanan, pengurusan masa, komunikasi pelajar-pensyarah, penyesuaian, gaya asuhan ibu bapa, penghargaan kendiri pelajar, beban tugas akademik, persekitaran fizikal kampus dan pengajaran pensyarah) yang paling dominan mempengaruhi masalah pelajar.

2. Mengenalpasti hubungan di antara faktor tekanan akademik dan penyesuaian dengan faktor-faktor lain.

3. Mengenalpasti perbezaan demografi berdasarkan faktor jantina, bangsa dan jurusan pengajian.

4. Mengemukakan cadangan bagi membantu pelajar dalam menjalani kehidupan di universiti.

\section{METOD KAJIAN}

Populasidan-Sampel

Populasi kajian adalah merangkumi keseluruhan pelajar ijazah Sarjana Muda Universiti Utara Malaysia, iaitu seramai 18,356 orang mengikut statistik kemasukan sesi 2003/2004 (Jabatan Hal Ehwal Akademik, 2003). Disebabkan terdapat variasi yang banyak dari segi demografi sampel yang terlibat, pemilihan sampel dibuat secara rawak berstratifikasi berdasarkan jantina dan fakulti. Ini adalah bagi menyeimbangkan aspek demografi utama iaitu jantina dan fakulti. Jumlah keseluruhan borang soal selidik yang diedarkan ialah sebanyak 2000. Jumlah yang dikembalikan adalah sebanyak 1923 orang ataupun 10.5 peratus dari keseluruhan populasi kajian manakala bakinya tidak dipulangkan atau rosak. Jumlah ini adalah melebihi dari jumlah yang dicadangkan oleh Krejcie dan Morgan (1970) iaitu seramai 377 orang sampel bagi setiap 20,000 orang dalam sesuatu populasi. Pembahagian pemilihan sampel mengikut jantina (30\% lelaki dan 70\% perempuan) dan fakulti ialah seperti di dalam Jadual 1.

\section{Jadual 1}


3, skor 4 diterbalikkan menjadi 2 bagi item negatif dan yang terakhir sekali 5 bagi item positif diterbalikkan menjadi 1 bagi item negatif. Jumlah skor bagi setiap alat ukuran diperolehi dengan menjumlahkan keseluruhan skor item-item yang ditandakan. Seterusnya, daripada nilai minimum dan maksimum yang diperolehi, pembahagian markah dibuat dengan membahagikan setiap tahap kepada tiga kategori iaitu rendah, sederhana dan tinggi. Pembahagian markah adalah seperti Jadual 3.

\section{Jadual 3}

\section{Nilai Minimum dan Maksimum serta Pembahagian Markah}

\begin{tabular}{|c|c|c|c|c|c|}
\hline Tahap & Nilai & Nilai & \multicolumn{3}{|c|}{ Pembahagian Markah } \\
\hline & Minimum & Maksimum & Rendah & Sederhana & Tinggi \\
\hline Tekanan & 34 & 170 & $34-79$ & $80-124$ & $125-170$ \\
\hline akademik & $(34$ item $\times 1)$ & (34 item x 5) & & & \\
\hline $\begin{array}{l}\text { Pengurusan } \\
\text { masa }\end{array}$ & $\begin{array}{c}29 \\
\text { (29 item x 1) }\end{array}$ & $\begin{array}{c}145 \\
(29 \text { item x 5) }\end{array}$ & $29-67$ & $68-106$ & $107-145$ \\
\hline Penyesuaian & $\begin{array}{c}42 \\
(42 \text { item x 1) }\end{array}$ & $\begin{array}{c}210 \\
(42 \text { item } \times 5)\end{array}$ & $42-98$ & $99-155$ & $156-210$ \\
\hline $\begin{array}{l}\text { Penghargaan } \\
\text { kendiri }\end{array}$ & $\begin{array}{c}10 \\
(10 \text { item } \times 1)\end{array}$ & $\begin{array}{c}50 \\
(10 \text { item x 5) }\end{array}$ & $10-23$ & $24-37$ & $38-50$ \\
\hline $\begin{array}{l}\text { Beban } \\
\text { tugas }\end{array}$ & $\begin{array}{c}7 \\
(7 \text { item } x 1)\end{array}$ & $\begin{array}{c}35 \\
(7 \text { item x 5) }\end{array}$ & $7-16$ & $17-25$ & $26-35$ \\
\hline Persekitaran & $\begin{array}{c}11 \\
(11 \text { item } \times 1)\end{array}$ & $\begin{array}{c}55 \\
(11 \text { item } \times 5)\end{array}$ & $11-25$ & $26-39$ & $40-55$ \\
\hline Gaya asuhan & $\begin{array}{c}18 \\
(18 \text { item x 1) }\end{array}$ & $\begin{array}{c}90 \\
(18 \text { item x 5) }\end{array}$ & $18-42$ & $43-66$ & $67-90$ \\
\hline Pengajaran & $\begin{array}{c}26 \\
(26 \text { item x 1) }\end{array}$ & $\begin{array}{c}130 \\
(26 \text { item x 5) }\end{array}$ & $26-60$ & $61-95$ & $96-130$ \\
\hline Komunikasi & $\begin{array}{c}36 \\
(36 \text { item x 1) }\end{array}$ & $\begin{array}{c}180 \\
(36 \text { item x 5) }\end{array}$ & $36-84$ & $85-132$ & $133-180$ \\
\hline
\end{tabular}

\section{Analisis Data}

Data yang dikumpul, dianalisis secara deskriptif dan inferensi melalui penggunaan pakej statistik SPSS (Statistical Package for Social Sciences). Untuk analisis deskriptif, kajian ini menggunakan peratusan, min dan carta 
Bahagian $\mathrm{H} \quad$ : $\quad$ Mengukur faktor gaya asuhan ibu bapa/penjaga.

Bahagian I : $\quad$ Mengukur pengajaran pensyarah.

Bahagian J : $\quad$ Mengukur komunikasi pensyarah-pelajar.

Skala Likert lima poin digunakan sebagai pilihan jawapan bagi setiap bahagian kecuali bahagian demografi. Instrumen yang digunakan dapat dilihat dalam Jadual 2.

Jadual 2

Instrumen Yang Digunakan

\begin{tabular}{|c|c|c|}
\hline Faktor & Instrumen/Rujukan & $\begin{array}{c}\begin{array}{c}\text { Bilangan } \\
\text { item }\end{array} \\
\end{array}$ \\
\hline Tekanan akademik & Academic Stress Questionnaire & 34 item \\
\hline Pengurusan masa & $\begin{array}{l}\text { Time Management Behavior (TMB) } \\
\text { (Macan et al, 1990; Macan, 1994) }\end{array}$ & 29 item \\
\hline $\begin{array}{l}\text { Penyesuaian pelajar } \\
\text { dalam universiti }\end{array}$ & $\begin{array}{l}\text { Naz \& Weber (2003); Missisipi } \\
\text { International Student Problem } \\
\text { Inventory (MISPI) (Porter, 1962) }\end{array}$ & 42 item \\
\hline Penghargaan kendiri & $\begin{array}{l}\text { Penghargaan Kendiri Rosenberg } \\
\text { (Robinson \& Shaver, 1973) }\end{array}$ & 10 item \\
\hline Beban tugas & Chambers (1992); Kember \& Ng (1996) & 7 item \\
\hline $\begin{array}{l}\text { Persekitaran } \\
\text { Pembelajaran }\end{array}$ & Bojuwoye (2002) & 11 item \\
\hline Gaya asuhan ibu bapa & McClun \& Merrell (1998) & 18 item \\
\hline Pengajaran & UTLC & 26 item \\
\hline $\begin{array}{l}\text { Komunikasi pensyarah- } \\
\text { pelajar }\end{array}$ & Burgoon \& Hale (1984) & 36 item \\
\hline
\end{tabular}

Bagi mengukur tahap tekanan akademik, pengurusan masa, penyesuaian, penghargaan kendiri, beban tugas, persekitaran, gaya asuhan, pengajaran pensyarah dan komunikasi, kaedah permarkahan terbalik dilakukan bagi item yang bersifat negatif. Skor 1 untuk item positif diterbalikkan menjadi 5 bagi item negatif, item 2 diterbalikkan menjadi 4, manakala skor 3 tetap menjadi 
tekanan akademik bagi responden perempuan adalah lebih rendah dari responden lelaki. Bagi responden perempuan beban tugas merupakan faktor yang paling rendah dalam kategori tinggi, manakala bagi responden lelaki beban tugas adalah yang ketiga terendah dalam kategori tinggi. Ini bermaksud beban tugas responden perempuan adalah lebih rendah berbanding dengan responden lelaki (Rajah 1).

Berdasarkan faktor jantina, penyesuaian merupakan faktor yang paling tinggi kekerapannya bagi pelajar lelaki dan perempuan. Ini bermakna pelajar UUM tidak kira lelaki atau perempuan boleh menyesuaikan diri dengan baik kepada persekitaran, pengajaran dan pembelajaran di UUM. Faktor kedua dominan kepada pelajar lelaki ialah faktor komunikasi pensyarah-pelajar, namun bagi pelajar perempuan faktor ini merupakan faktor ketiga tertinggi. Menurut Brophy (1985) dan Hite (1985), pengajar biasanya memberikan perhatian yang lebih kepada pelajar lelaki. Salah satu sebab mengapa kurangnya interaksi antara pengajar lelaki dengan pelajar perempuan adalah bagi mengelakkan khabarkhabar negatif tentang mereka seperti mempunyai hubungan intim dengan pelajar. Manakala bagi pelajar perempuan faktor kedua dominan adalah faktor penghargaan kendiri tetapi faktor ini merupakan faktor keempat tertinggi bagi pelajar lelaki. Ini bermakna faktor penyesuaian, komunikasi pensyarah pelajar dan penghargaan kendiri merupakan faktor-faktor yang paling dominan kepada pelajar lelaki dan perempuan.

Jadual 4

\section{Kedudukan Profil Masalah Mengikut Jantina}

$\begin{array}{cll}\text { Kedudukan } & \text { Lelaki } & \text { Perempuan } \\ 1 & \text { Penyesuaian } & \text { Penyesuaian } \\ 2 & \text { Komunikasi Pensyarah-pelajar } & \text { Penghargaan Kendiri } \\ 3 & \text { Pengajaran Pensyarah } & \text { Komunikasi Pensyarah-pelajar } \\ 4 & \text { Penghargaan Kendiri } & \text { Pengurusan Masa } \\ 5 & \text { Gaya Asuhan } & \text { Pengajaran Pensyarah } \\ 6 & \text { Pengurusan Masa } & \text { Gaya Asuhan } \\ 7 & \text { Beban Tugas } & \text { Tekanan Akademik } \\ 8 & \text { Persekitaran } & \text { Persekitaran } \\ 9 & \text { Tekanan Akademik } & \text { Beban Tugas }\end{array}$

Bagi kategori etnik, hasil kajian menunjukkan etnik Melayu, Cina dan India meletakkan faktor penyesuaian sebagai faktor yang paling dominan. Manakala 
yang bersesuaian. Manakala untuk analisis inferensi, kajian ini menggunakan Ujian t, Analisis Varians Satu Hala (ANOVA) dan Korelasi Pearson.

\section{KEPUTUSAN DAN PERBINCANGAN}

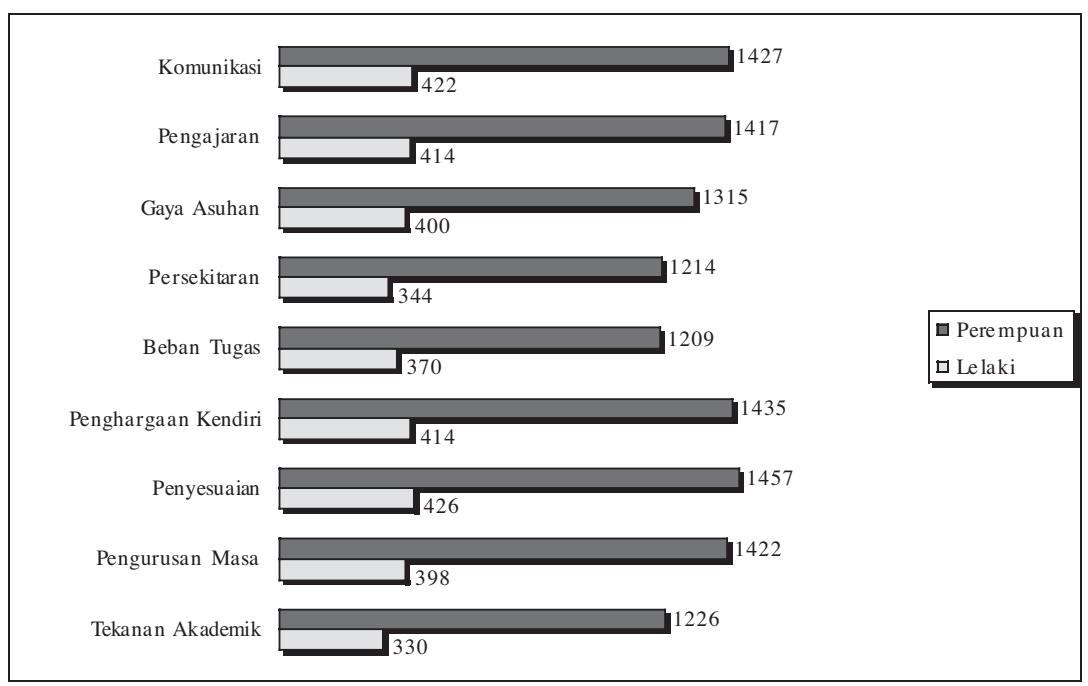

Rajah 1

Skor bagi setiap faktor mengikut faktor jantina

Analisis menunjukkan majoriti responden berada di tahap kategori tinggi. Skor faktor dalam kategori tinggi dianalisis berdasarkan responden yang mendapat skor dalam kategori tinggi bagi setiap faktor.

Jantina

Skor faktor dalam kategori tinggi bagi responden lelaki ialah penyesuaian (426 orang). Kemudian diikuti oleh komunikasi pensyarah-pelajar (422 orang), pengajaran pensyarah dan penghargaan kendiri (414 orang), gaya asuhan (400 orang), pengurusan masa (398 orang), beban tugas (370 orang), persekitaran (344 orang) dan tekanan akademik (330 orang). Manakala bagi responden perempuan yang berada dalam kategori tinggi ialah penyesuaian (1,457 orang), penghargaan kendiri (1,435 orang), komunikasi pensyarah-pelajar (1,427 orang), pengurusan masa (1,422 orang), pengajaran pensyarah (1,417 orang), gaya asuhan (1,315 orang), tekanan akademik (1,226 orang), persekitaran (1,214 orang) dan beban tugas (1,209 orang). Bagi responden lelaki tekanan akademik merupakan faktor yang terendah dalam kategori skor tinggi manakala bagi

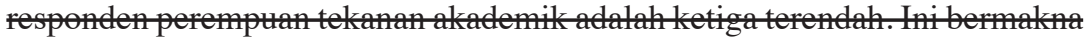




$\begin{array}{lllll}8 & \text { Tekanan } & \text { Tekanan } & \text { Tekanan } & \text { Beban Tugas } \\ & \text { Akademik } & \text { Akademik } & \text { Akademik } & \\ 9 & \text { Beban Tugas } & \text { Persekitaran } & \text { Beban Tugas } & \text { Penyesuaian }\end{array}$

\section{Korelasi}

Analisis korelasi memperlihatkan faktor tekanan akademik mempunyai hubungan korelasi dengan beberapa faktor (Jadual 6) seperti pengurusan masa $(\mathrm{r}=0.6, \mathrm{p}<0.01)$ iaitu semakin baik seorang pelajar itu mengurus masanya semakin kurang tekanan akademik yang dihadapinya. Tekanan akademik didapati mempunyai hubungan yang lemah dengan penghargaan kendiri $(\mathrm{r}$ $=-0.08, \mathrm{p}<0.01)$, namun hubungan ini bersifat negatif iaitu semakin rendah nilai penghargaan kendiri di dalam diri pelajar terbabit semakin tinggi tekanan akademik yang dihadapi, atau semakin tinggi nilai penghargaan kendiri yang dimiliki oleh pelajar terbabit, semakin kurang tekanan akademik yang dihadapinya. Bagi hubungan di antara tekanan akademik dengan beban tugas $(\mathrm{r}=0.21, \mathrm{p}<0.01)$ pula dapat dilihat bahawa semakin banyak beban tugas yang dihadapi semakin tinggi tekanan akademik yang dirasakan, sebaliknya semakin kurang beban tugas yang dihadapi semakin kurang tekanan akademik yang dirasai oleh seseorang pelajar. Gaya asuhan juga dilihat mempunyai hubungan dengan tekanan akademik $(r=0.08, p<0.01)$. Ini menunjukkan bahawa semakin baik gaya asuhan yang diberikan oleh keluarga maka semakin bijak mereka mengawal tekanan akademik. Hasil kajian ini selaras dengan dapatan kajian

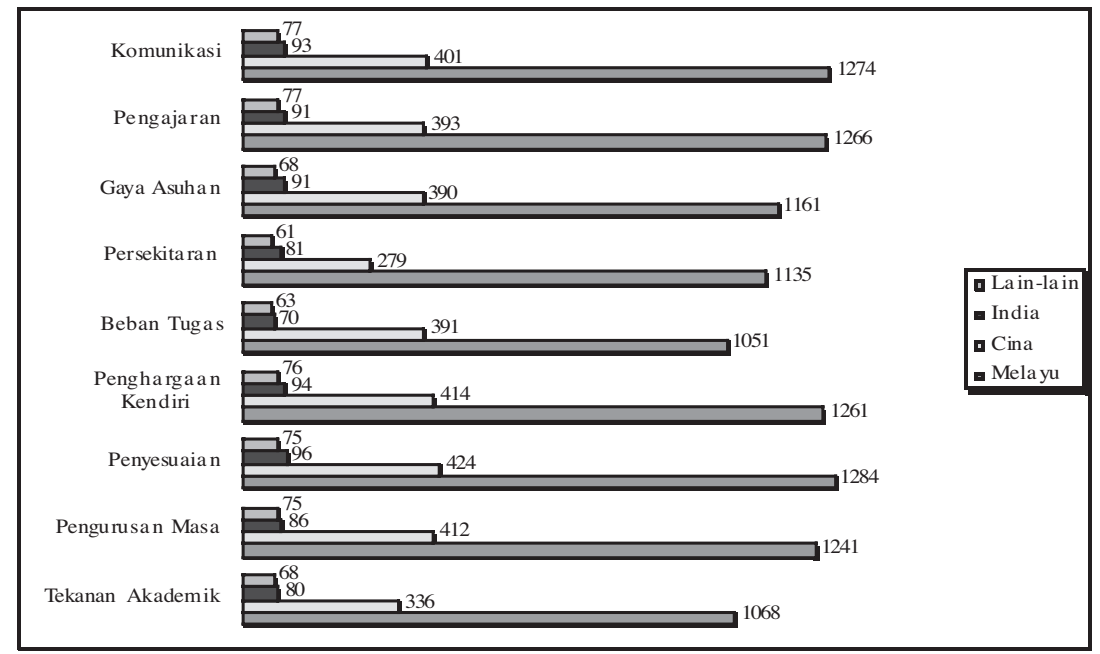

Rajah 2

Skor bagi setiap faktor mengikut faktor etnik 
faktor beban tugas bagi etnik Melayu, faktor persekitaran bagi etnik Cina dan faktor beban tugas bagi etnik India merupakan faktor yang paling rendah dari segi hiraki dominan. Dalam lain-lain etnik, di dapati pengajaran pensyarah dan komunikasi pensyarah-pelajar merupakan faktor yang paling dominan dan persekitaran merupakan faktor yang paling rendah (Rajah 2 dan Jadual 5).

Berdasarkan Jadual 5, keputusan dari aspek etnik menunjukkan faktor yang paling dominan adalah penyesuaian, penghargaan kendiri, pengurusan masa, komunikasi pensyarah-pelajar dan pengajaran pensyarah. Bagi pelajar Melayu, Cina dan India, faktor penyesuaian adalah faktor yang paling dominan. Manakala bagi pelajar dari bangsa-bangsa lain, faktor yang paling dominan ialah komunikasi pensyarah-pelajar. Faktor kedua tertinggi adalah komunikasi bagi pelajar Melayu, penghargaan kendiri bagi pelajar Cina dan India, dan pengajaran pensyarah bagi pelajar bangsa lain. Faktor ketiga tertinggi adalah tahap pengajaran pensyarah bagi pelajar Melayu, pengurusan masa bagi pelajar Cina, komunikasi bagi pelajar India dan penghargaan kendiri bagi pelajar bangsa lain. Dapatan ini juga menunjukkan bahawa faktor penghargaan kendiri merupakan antara faktor yang paling dominan kepada pelajar bukan Bumiputera. Apabila pelajar merasakan mereka setanding dengan orang lain, dan mempunyai banyak kualiti yang positif, mereka akan lebih yakin terhadap diri sendiri untuk berkomunikasi dengan pensyarah, bercakap di hadapan kelas dan orang ramai, serta mampu menyesuaikan diri dengan persekitaran.

\section{Jadual 5}

Kedudukan Profil Masalah Mengikut Etnik

\begin{tabular}{|c|c|c|c|c|}
\hline Kedudukan & Melayu & Cina & India & Lain-lain Etnik \\
\hline 1 & Penyesuaian & Penyesuaian & Penyesuaian & $\begin{array}{l}\text { Komunikasi } \\
\text { Pensyarah- }\end{array}$ \\
\hline \multicolumn{5}{|l|}{ pelajar } \\
\hline \multirow[t]{2}{*}{2} & Komunikasi & Penghargaan & Penghargaan & Pengajaran \\
\hline & $\begin{array}{l}\text { Pensyarah- } \\
\text { pelajar }\end{array}$ & Kendiri & Kendiri & Pensyarah \\
\hline 3 & $\begin{array}{l}\text { Pengajaran } \\
\text { Pensyarah }\end{array}$ & $\begin{array}{l}\text { Pengurusan } \\
\text { masa }\end{array}$ & Komunikasi & $\begin{array}{l}\text { Penghargaan } \\
\text { Kendiri }\end{array}$ \\
\hline 4 & Penghargaan & Komunikasi & Pengajaran & Pengurusan Masa \\
\hline & Pensyarah & Kendiri & $\begin{array}{l}\text { Pensyarah- } \\
\text { pelajar }\end{array}$ & \\
\hline 5 & Pengurusan & Pengajaran & Gaya Asuhan & Penyesuaian \\
\hline Masa & Pensyarah & & & \\
\hline 6 & Gaya Asuhan & Beban tugas & $\begin{array}{l}\text { Pengurusan } \\
\text { masa }\end{array}$ & Gaya Asuhan \\
\hline 7 & Persekitaran & Gaya Asuhan & Persekitaran & $\begin{array}{l}\text { Tekanan } \\
\text { Akademik }\end{array}$ \\
\hline
\end{tabular}


menjadi pembimbing kepada anak-anak. Gaya asuhan ini membentuk anakanak untuk menjadi tegas, bertanggungjawab, dapat mengurus diri dan boleh bekerjasama selaras dengan teori yang berkaitan dengan hubungan interpersonal yang bebas dan pembangunan autonomi individu.

Jadual 6

Korelasi antara Faktor Tekanan Akademik dengan Faktor-Faktor Lain

\begin{tabular}{|c|c|c|c|c|}
\hline & $\begin{array}{c}\text { Pengurusan } \\
\text { Masa }\end{array}$ & $\begin{array}{c}\text { Penghargaan } \\
\text { Kendiri }\end{array}$ & $\begin{array}{l}\text { Beban } \\
\text { Tugas }\end{array}$ & Gaya \\
\hline Asuhan & & & & \\
\hline $\begin{array}{l}\text { Tekanan } \\
\text { Akademik }\end{array}$ & $0.16^{* *}$ & $-0.08 * *$ & $0.21 * *$ & $0.08 * *$ \\
\hline
\end{tabular}

Faktor penyesuaian (Jadual 7) pula mempunyai hubungan korelasi dengan penghargaan kendiri $(\mathrm{r}=0.38, \mathrm{p}<0.01)$ iaitu semakin tinggi nilai penghargaan kendiri yang dimiliki oleh seseorang pelajar, semakin mudah untuk mereka menyesuaikan diri di tempat belajar. Sebaliknya semakin rendah nilai penghargaan kendiri yang dimiliki oleh seseorang pelajar, semakin sukar untuk seseorang pelajar itu menyesuaikan diri di tempat belajar. Begitu juga dengan faktor beban tugas $(\mathrm{r}=-0.21, \mathrm{p}<0.01)$. Bagaimanapun hubungan di antara faktor beban tugas dengan penyesuaian pula adalah bersifat negatif. Ini menunjukkan bahawa semakin tinggi beban tugas yang dirasakan oleh pelajar semakin sukar dirasakan untuk mereka menyesuaikan diri di tempat belajar. Sebaliknya semakin kurang beban tugas yang dirasakan akan menyebabkan seseorang pelajar itu merasakan semakin mudah penyesuaian di tempat belajar. Penyesuaian juga mempunyai hubungan korelasi dengan persekitaran $(\mathrm{r}=0.35$, $\mathrm{p}<.01$ ). Ini menunjukkan bahawa semakin baik persekitaran yang dirasakan oleh pelajar, semakin mudah untuk mereka menyesuaikan diri. Sebaliknya semakin sukar persekitaran yang dihadapinya, semakin sukar untuknya menyesuaikan diri. Hubungan penyesuaian dengan gaya asuhan $(\mathrm{r}=0.19, \mathrm{p}<0.01)$ pula memperlihatkan semakin baik gaya asuhan yang diterima oleh pelajar terbabit semakin mudah baginya menyesuaikan diri. Sebaliknya semakin buruk gaya asuhan yang diterima semakin sukar baginya untuk menyesuaikan diri. Semakin baik bentuk pengajaran pensyarah yang disampaikan kepada pelajar terbabit ( $\mathrm{r}$ $=0.34, \mathrm{p}<0.01$ ), semakin mudah baginya untuk menyesuaikan diri. Sebaliknya semakin kemah bentuk pengajaran pensyarah yang diterimanya, semakin sukar untuk pelajar terbabit menyesuaikan diri. Hubungan korelasi dengan faktor komunikasi pensyarah-pelajar $(r=0.25, \mathrm{p}<0.01)$ menunjukkan semakin baik komunikasi pensyarah-pelajar, semakin mudah bagi pelajar terbabit menyesuaikan diri. Sebaliknya semakin kurang komunikasi antara pensyarah- 
yang dijalankan oleh Institute for Social Research (1999) yang menunjukkan walaupun tahap pengurusan pelajar adalah sederhana, pengurusan masa semakin bertambah baik selaras dengan peningkatan tahun pengajian. Dapatan yang sama juga turut ditunjukkan oleh Macan (1994) yang mendapati terdapat hubungan antara pengurusan masa dengan prestasi akademik, dan prestasi kerja. Hasil kajian ini juga menunjukkan wujudnya persamaan dengan andaian teori yang menyatakan kepentingan pengurusan emosi dari segi cara mengatasi masalah tekanan akademik dengan pembangunan autonomi iaitu pengurusan masa. Kajian ini berpendapat pengurusan masa yang baik dan berkesan membantu mengurangkan tekanan akademik yang dihadapi para pelajar.

Bagi hubungan antara tekanan akademik dengan penghargaan kendiri, hasil kajian ini menunjukkan terdapat hubungan yang signifikan, lemah dan positif antara kedua-dua faktor berkenaan. Dapatan ini menunjukkan semakin rendah penghargaan kendiri, maka semakin tinggi tekanan akademik. Manakala semakin tinggi penghargan kendiri, semakin rendaht tekanan akatemik. Penghargan kendiri dalam konteks kajian ini dilihat sebagai nilai yang diletakkan oleh individu terhadap diri mereka. Nilai yang positif dikaitkan dengan kurangnya tekanatemik. Đapatan ini setaras dengan kajian oleh Abotrserie (1994), Rosenberg (Orenstein, 1994), Brown dan Taylor (1989), Wiggins (1987) dan Hamacheck (1995). Dapatan kajian ini jelas menunjukkan korelasi positif antara penghargaan kendiri dengan prestasi akademik, sekaligus menunjukkan andaian teori bahawa pengurusan emosi turut mempunyai perkaitan dengan kestabilan identiti.

Dari segi tekanan akademik dan beban tugas, hasil kajian mendapati keduaduanya mempunyai perkaitan yang positif iaitu semakin tinggi beban tugas yang dipikul oleh seseorang pelajar, semakin tinggi tekanan akademik yang dialaminya. Dapatan ini menyokong teori yang diaplikasikan dalam kajian ini iaitu perkaitan antara pengurusan emosi dan pembangunan autonomi. Dari segi beban tugas, sebagai seorang pelajar biasanya mereka dikehendaki mengambil pelbagai kursus di dalam bidang pengkhususan dan elektif. Bebanan tugas yang dipikul ini mengundang tekanan kepada mereka serta mencabar mereka supaya menangani masalah ini dengan bijak. Bagi menangani masalah bebanan tugas ini, mereka harus bijak dari segi mengurus emosi atau tekanan yang dialami oleh mereka. Kegagalan mereka berbuat demikian, akan menyumbang kepada prestasi akademik yang rendah. Berdasarkan kajian lepas, salah satu faktor yang boleh menyumbang kepada kurangnya tekanan akademik yang dialami oleh pelajar ialah asuhan ibu bapa. Gaya asuhan ibu bapa yang baik menyebabkan pelajar bijak mengawal tekanan akademik. Dapatan ini selaras dengan kajian oleh McClun dan Merrell (1998), Baumrind (1991) serta Darling dan Steinberg (1993). Kajian ini menunjukkan gaya asuhan mempunyai perkaitan dengan tekanan akademik dan prestasi pelajar. Gaya asuhan yang mempunyai perkaitan paling tinggi dengan prestasi akademik ialah autoritatif iaitu ibubapa yang 
perkaitan yang signifikan. Ini menunjukkan persekitaran yang kondusif dan menyokong kepada pengajaran dan pembelajaran dapat membantu pelajar menyesuaikan diri mereka dengan keadaan serta kehidupan di kampus.

Tugas dan peranan pensyarah tidak hanya terhad kepada bilik kuliah sahaja. Komunikasi yang berlaku antara kedua belah pihak didapati dapat membantu pelajar menyesuaikan diri dengan keadaan di kampus. Dapatan ini selaras dengan kajian yang dijalankan oleh Splinder dan Goldschmidt (Suradi, 1984) dalam kajian mereka untuk melihat tahap interaksi dengan adaptasi. Hasil kajian mendapati pelajar-pelajar asing yang cuba memperbanyakkan interaksi mereka dengan pelajar-pelajar negara tuan rumah akan lebih cepat menyesuarkan diri. Salah satu daripada interaksi berkenaan ialah cara komunikasi dengan pensyarah.

\section{Perbezaan Demografi: Jantina}

Hasil analisis Ujian-t mendapati lima faktor iaitu tekanan akademik, pengurusan masa, penyesuaian, gaya asuhan dan komunikasi pensyarah-pelajar mempunyai perbezaan yang signifikan dalam aspek jantina (Jadual 8). Bagi tekanan akademik, responden perempuan mempunyai min yang lebih tinggi daripada lelaki. Ini bermakna responden perempuan mengalami tekanan akademik yang lebih tinggi berbanding lelaki. Bagi faktor pengurusan masa, nilai min bagi responden perempuan lebih tinggi daripada responden lelaki. Ini menunjukkan responden perempuan menguruskan masa lebih baik daripada responden lelaki. Bagi faktor penyesuaian, nilai min bagi responden perempuan adalah lebih tinggi berbanding responden lelaki, dan menunjukkan responden perempuan dapat menyesuaikan diri dengan lebih baik berbanding responden lelaki. Manakala dari segi gaya asuhan pula nilai min bagi responden lelaki adalah lebih tinggi berbanding responden perempuan. Ini bererti responden lelaki dipersepsikan sebagai menerima asuhan yang baik daripada ibubapa mereka. Hasil analisis bagi faktor komunikasi pensyarah-pelajar pula menunjukkan nilai min bagi responden lelaki adalah lebih tinggi berbanding responden perempuan. Dengan kata lain, komunikasi pensyarah-pelajar adalah lebih baik bagi pelajar lelaki berbanding pelajar perempuan Secara keseluruhannya faktor jantina dengan faktor yang dikaji menunjukkan tiga faktor iaitu min lebih tinggi bagi pelajar perempuan iaitu tekanan akademik, pengurusan masa dan penyesuaian, manakala bagi pelajar lelaki ialah gaya asuhan dan komunikasi pensyarah-pelajar.

\section{Jadual 8}

\section{Analisis Ujian-t Faktor-Faktor Berdasarkan Jantina}

$\begin{array}{lccccr}\text { Faktor } & \text { Jantina } & \text { N } & \text { Min } & \text { T } & \text { df } \\ \text { Tekanan Akademik } & \text { Lelaki } & 436 & 103.32 & -3.40 * * * & 1916\end{array}$


pelajar, semakin sukar bagi pelajar menyesuaikan dirinya.

\section{Jadual 7}

Korelasi antara Faktor Penyesuaian dengan Faktor-Faktor Lain

\begin{tabular}{|c|c|c|c|c|c|c|}
\hline & $\begin{array}{c}\text { Penghargaan } \\
\text { Kendiri }\end{array}$ & $\begin{array}{l}\text { Beban } \\
\text { Tugas }\end{array}$ & Persekitaran & $\begin{array}{l}\text { Gaya } \\
\text { Asuhan }\end{array}$ & $\begin{array}{l}\text { Pengajaran } \\
\text { Pensyarah }\end{array}$ & $\begin{array}{c}\text { Komunikasi } \\
\text { Pensyarah } \\
\text { Pelajar }\end{array}$ \\
\hline Penyesuaian & $0.38 * *$ & $-0.21 * *$ & $0.35^{* *}$ & $0.19 * *$ & $0.34 * *$ & $0.25 * *$ \\
\hline
\end{tabular}

Hubungan antara kedua-dua faktor iaitu penyesuaian dan penghargaan kendiri yang positif menunjukkan semakin tinggi penghargaan kendiri, semakin bijak pelajar menyesuaikan diri dengan keadaan kehidupan di kampus. Kepentingan tahap penghargaan kendiri ini turut diakui oleh Abouserie (1984), Rosenberg (Orenstein, 1994) serta Brown dan Taylor (1988). Sehubungan itu, kajian ini menunjukkan selain daripada prestasi akademik, terdapat faktor lain yang boleh dikaitkan iaitu penghargaan kendiri, penyesuaian pelajar dengan persekitaran di kampus dan corak pembelajaran di universiti. Hubungan antara beban tugas dan penyesuaian yang negatif mencerminkan bahawa beban tugas yang banyak, yang dipikul oleh pelajar akan menyukarkan mereka menyesuaikan diri dengan persekitaran di kampus. Dapatan ini selaras dengan kajian yang dijalankan dalam proses penyesuaian iaitu kesihatan, kewangan, sosial, sosiopsikologikal, peribadi, akhlak, rumahtangga, masa depan, penyesuaian kerja sekolah dan akademik termasuklah beban tugas (Kember \& Ng, 1996). Kajian ini mendapati persepsi terhadap beban tugas turut mempengaruhi penyesuaian para pelajar dalam konteks menggunakan kaedah pembelajaran yang sesuai.

Fenomena yang sama turut didapati dari segi hubungan antara gaya asuhan dan penyesuaian. Gaya asuhan yang diterima daripada ibu bapa didapati turut membantu para pelajar menyesuaikan diri dengan keadaan di kampus. Dapatan ini selaras dengan kajian yang dijalankan oleh Lynette (Suradi, 1984)) yang mengkaji hubungan antara keadaan psikologi pelajar yang terhasil daripada gaya asuhan dengan proses penyesuaian terhadap kehidupan di kolej. Beliau turut mendapati pelajar lelaki kurang bergantung kepada keluarga berbanding pelajar perempuan. Dapatan ini berpendapat tahap bimbingan dan kebebasan yang diberikan oleh ibu bapa dalam mendidik anak-anak dapat membantu proses adaptasi pelajar di universiti. Hubungan antara persekitaran dan penyesuaian pula mendapati kedua-dua faktor iaitu persekitaran dan penyesuaian mempunyai 
Jadual 9

\begin{tabular}{|c|c|c|c|c|}
\hline \multicolumn{5}{|c|}{ Analisis ANOVA Faktor-Faktor Berdasarkan Etnik } \\
\hline \multicolumn{2}{|l|}{ Faktor } & df & Mean Square & $\mathrm{F}$ \\
\hline \multirow[t]{3}{*}{ Tekanan Akademik } & Antara kumpulan & 3 & 1595.91 & $4.52 * * *$ \\
\hline & Dalam kumpulan & 1908 & 352.85 & \\
\hline & Jumlah & 1911 & & \\
\hline \multirow[t]{3}{*}{ Pengurusan Masa } & Antara kumpulan & 3 & 1322.97 & $6.34 * * *$ \\
\hline & Dalam kumpulan & 1907 & 208.81 & \\
\hline & Jumlah & 1910 & & \\
\hline \multirow[t]{3}{*}{ Penyesuaian } & Antara kumpulan & 3 & 5380.27 & $28.71 * * *$ \\
\hline & Dalam kumpulan & 1908 & 187.40 & \\
\hline & Jumlah & 1911 & & \\
\hline \multirow[t]{3}{*}{ Penghargaan Kendiri } & Antara kumpulan & 3 & 489.17 & $14.04 * * *$ \\
\hline & Dalam kumpulan & 1905 & 34.83 & \\
\hline & Jumlah & 1908 & & \\
\hline \multirow[t]{3}{*}{ Beban Tugas } & Antara kumpulan & 3 & 461.29 & $17.95 * * *$ \\
\hline & Dalam kumpulan & 1899 & 25.70 & \\
\hline & Jumlah & 1902 & & \\
\hline \multirow[t]{3}{*}{ Persekitaran } & Antara kumpulan & 3 & 3206.59 & $59.31 * * *$ \\
\hline & Dalam kumpulan & 1905 & 54.07 & \\
\hline & Jumlah & 1908 & & \\
\hline \multirow[t]{3}{*}{ Pengajaran Pensyarah } & Antara kumpulan & 3 & 10246.06 & $41.39 * * *$ \\
\hline & Dalam kumpulan & 1905 & 247.56 & \\
\hline & Jumlah & 1908 & & \\
\hline \multirow[t]{3}{*}{ Komunikasi } & Antara kumpulan & 3 & 5971.29 & $30.55^{* * *}$ \\
\hline & Dalam kumpulan & 1901 & 195.44 & \\
\hline & Jumlah & 1904 & & \\
\hline
\end{tabular}

Setelah ujian Post-hoc Scheffe dijalankan, responden etnik Melayu didapati menghadapi tekanan akademik yang lebih tinggi, walaupun mereka merasakan mempunyai tahap beban tugas yang lebih rendah berbanding responden etnik Cina. Responden etnik Melayu juga melaporkan bahawa mereka dapat menguruskan masa, menyesuaikan diri dengan pembelajaran dan persekitaran fizikal UUM, mempunyai tahap pengajaran dan komunikasi yang lebih baik berbanding responden etnik Cina. Dapatan ini tidak menyokong dapatan kajian 


\begin{tabular}{llcccc} 
& Perempuan & 1481 & 107.34 & & \\
Pengurusan Masa & Lelaki & 435 & 98.66 & $-3.69^{* * *}$ & 1915 \\
& Perempuan & 1481 & 101.58 & & \\
Penyesuaian & Lelaki & 434 & 139.39 & $-2.31^{*}$ & 1914 \\
& Perempuan & 1481 & 141.16 & & \\
Gaya Asuhan & Lelaki & 434 & 57.94 & $2.27 *$ & 1912 \\
& Perempuan & 1479 & 56.94 & & \\
Komunikasi & Lelaki & 432 & 120.23 & $3.06^{* *}$ & 1907 \\
& Perempuan & 1476 & 117.84 & & \\
\hline
\end{tabular}

$* p<0.05, * * p<0.01, * * * p<0.001$

Responden perempuan yang menghadapi tekanan akademik yang lebih tinggi daripada responden lelaki mempunyai persamaan dengan dapatan kajian yang dilakukan oleh Abouserie (1994). Namun ia bertentangan dengan kajian Macan (1994). Abouserie (1994) berpendapat aktiviti berkaitan akademik seperti peperiksaan, terlalu banyak tugasan, kehendak diri untuk cemerlang dan membuat esei atau projek merupakan punca kepada tekanan. Mereka yang lebih banyak menggunakan kepercayaan kawalan luaran juga akan melaporkan tahap tekanan yang lebih tinggi. Namun begitu, responden perempuan dilaporkan dapat menguruskan masa lebih baik berbanding responden lelaki. Ranjita dan McKean (2000) serta Macan (1994) di dalam kajian mereka melaporkan dapatan yang sama. Macan (1994) percaya tingkahlaku pengurusan masa yang baik dapat mengurangkan tekanan akademik di kalangan pelajar. Dapatan kajian menunjukkan responden lelaki mempunyai gaya asuhan yang lebih positif daripada responden perempuan. Responden lelaki juga melaporkan mempunyai tahap komunikasi dengan pensyarah yang lebih baik berbanding responden perempuan. Kajian Debra dan Clifford (1999) mendapati dapatan yang berbeza iaitu faktor jantina tidak menentukan tahap hubungan dengan pensyarah yang berbeza. Perbezaannya hanya ditemui dalam interaksi yang melibatkan elemen psikososial sahaja dan bukan berkaitan dengan aspek akademik. Bagaimanapun dapatan Brophy (1985) menunjukkan hasil sebaliknya. Menurut beliau, pelajar lelaki lebih banyak mendapat perhatian pengajar sama ada berbentuk positif atau negatif.

\section{Perbezaan Demografi: Etnik}

Ujian ANOVA sehala dilakukan bagi melihat sama ada terdapat perbezaan dalam kategori etnik dengan semua faktor yang dikaji. Hasil analisis menunjukkan terelapat lapan faktor yang mempunyai perbezaan dari aspek etnik. Faktor tersebut ialah tekanan akademik, pengurusan masa, penyesuaian, penghargaan kendiri, beban tugas, persekitaran, pengajaran pensyarah dan komunikasi pensyarah-pelajar (Jadual 9). 


$\begin{array}{llcccc}\text { Beban Tugas } & \text { Teknikal } & 202 & 22.33 & -2.02 * & 1907 \\ & \text { bukan teknikal } & 1709 & 23.12 & & \\ \text { Persekitaran } & \begin{array}{l}\text { Teknikal } \\ \text { bukan teknikal }\end{array} & 202 & 38.19 & 3.25 * * * & 1913 \\ & & 36.58 & & \\ \text { Gaya Asuhan } & \begin{array}{l}\text { Teknikal } \\ \text { bukan teknikal }\end{array} & 202 & 56.44 & -2.08 * & 1914 \\ & 1716 & 57.25 & & \end{array}$

$* p<0.05$

$* * * p<0.001$

Responden yang mengambil jurusan teknikal mempersepsikan tahap persekitaran yang baik. Mereka juga mempunyai beban tugas dan tekanan akademik yang lebih rendah daripada responden jurusan bukan teknikal. Manakala responden jurusan bukan teknikal melaporkan mereka mempunyai tahap tekanan akademik dan beban tugas pada tahap yang lebih tinggi daripada responden jurusan teknikal. Walaupun begitu, kajian ini menunjukkan responden jurusan bukan teknikal mempunyai ibu bapa yang mengamalkan gaya asuhan yang lebih positif berbanding responden jurusan teknikal. Dapatan ini mengesahkan lagi pendapat Nouwens (1997) yang menyatakan apabila pelajar tidak dibebani dengan tugasan akademik seperti bahan bacaan dan tugasan yang banyak, pelajar akan merasakan beban tugas mereka berada di tahap yang rendah. Menurut Baumrind (1991) pula, ibu bapa yang mengamalkan didikan positif iaitu mengambil berat tentang pelajaran dan kejayaan anak-anak akan berupaya meningkatkan prestasi akademik anak-anak mereka.

\section{CADANGAN}

Walaupun kajian ini mendapati tidak terdapat permasalahan yang benar-benar meruncing dialami oleh pelajar kecuali masalah tekanan akademik dan beban tugas akademik, pihak pentadbiran universiti tidak seharusnya memandang ringan terhadap faktor-faktor tersebut. Justeru itu, dicadangkan langkahlangkah serta tindakan susulan yang boleh diterap sebagai strategi pencegahan dalam rangka usaha memastikan pelajar-pelajar dan pihak universiti dapat meminimakan masalah yang ada, sekaligus menjadi pemangkin kepada usaha menyelesaikan masalah yang dihadapi. Berdasarkan kepada hasil kajian dan perbincangan, dikemukakan beberapa cadangan seperti berikut:

Rancangan kerja pensyarah mestilah selaras dengan minggu perkuliahan. Begitu juga tugasan tidak harus dibebankan pada minggu pertama perkuliahan. Penilaian berterusan adalah digalakkan. Oleh itu, pensyarah haruslah memastikan kesesuaian pemberian tugasan akademik yang seiring dengan minggu kuliah. 
oleh Institute for Social Research (1999) yang menyatakan bahawa pelajar bukan Bumiputera mempunyai pengurusan masa yang lebih baik daripada

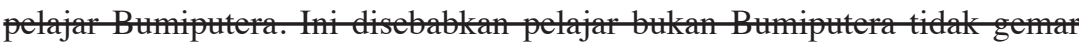
menangguhkan kerja sehingga ke saat akhir. Hasil kajian Morja dan rakan-rakan (2001) juga menclapati petajar bukan Bumiputera tebih kerapberjumpa tengan pensyarah. Sehubungan itu, pelajar bukan Bumiputera merasakan tekanan akademik mereka lebih rendah daripada pelajar Bumiputera.

Jika dibandingkan responden etnik Melayu dan India pula, responden etnik Melayu mempunyai tahap penyesuaian, persekitaran fizikal, tahap pengajaran dan tahap komunikasi dengan pensyarah yang lebih rendah daripada responden etnik India. Responden etnik India juga menganggap mereka mempunyai suasana pembelajaran yang lebih baik daripada responden etnik Cina apabila mereka menyatakan bahawa mereka mempunyai tahap penyesuaian, penghargaan kendiri, persekitaran, tahap pengajaran dan komunikasi yang Tebih baik daripada responden etnik Cina. Dapatan ini adalah relevan dengan pernyataan responden etnik Melayu yang menunjukkan tahap beban tugas mereka berada pada tahap yang lebih rendah. Responden lain-lain etnik juga melaporkan mereka mempunyai persekitaran, tahap pengajaran dan komunikasi yang lebih baik daripada responden etnik Cina. Namun responden etnik India mempunyai tahap penyesuaian dan komunikasi lebih baik daripada responden lain-lain etnik. Berdasarkan kepada Teori Pembangunan Pelajar oleh Chickering (1972), pelajar ini mempunyai keupayaan sosial dan interpersonal yang baik. Oleh itu mereka mampu berinteraksi walaupun dengan individu yang tidak dikenali. Secara tidak langsung, mereka dapat menyesuaikan diri dengan persekitaran sosial dan fizikal dengan lebih baik.

\section{Perbezaan Demografi: Jurusan Pengajian}

Terdapat empat faktor yang didapati mempunyai perbezaan daripada faktor jurusan kursus yang diambil oleh reponden. Berdasarkan analisis Ujian-t faktor tersebut ialah tekanan akademik, beban tugas, persekitaran dan gaya asuhan (Jadual 10). Bagi faktor tekanan akademik, beban tugas dan gaya asuhan pelajar yang mengambil jurusan bukan teknikal mendapat jumlah min yang tinggi, manakala bagi faktor persekitaran pula pelajar daripada jurusan teknikal mendapat jumlah min yang tinggi.

Jadual 10

\section{Analisis Ujian-t Faktor-Faktor Berdasarkan Jurusan Pengajian}

$\begin{array}{llcccc}\text { Faktor } & \text { Jurusan } & \text { N } & \text { Min } & \text { t } & \text { df } \\ \text { Tekanan Akademik } & \begin{array}{l}\text { Teknikal } \\ \text { bukan teknikal }\end{array} & 202 & 104.37 & -2.30 * & 1918\end{array}$


masalah besar yang dihadapi oleh pelajar UUM berdasarkan skor pelajar secara keseluruhan yang juga berada dalam kategori tinggi. Merujuk kepada hal ini, dapat disimpulkan bahawa pelaja:4r-pelajar UUM tidak mempunyai masalah besar yang begitu ketara kecuali bagi faktor tekanan akademik dan beban tugas.

Kebanyakan daripada faktor-faktor yang dinyatakan mempunyai hubungan di antara satu sama lain sama ada positif atau negatif. Perkaitan faktor-faktor ini tidak menghairankan memandangkan setiap satu daripada faktor ini mempunyai sejarah hubungan melalui kajian-kajian lepas yang pernah dilakukan oleh pengkaji lain. Dari segi demografi pula, setiap faktor yang dikaji mempunyai perbezaan berdasarkan jantina, etnik dan jurusan pengajian.

Walaupun permasalahan yang dihadapi oleh pelajar UUM tidak serius, namun pihak pengurusan universiti perlu sentiasa peka dengan permasalahan baru yang mungkin wujud. Pelajar datang serta pergi dalam jumlah yang tertentu setiap semester. Perkembangan fakulti, penambahan program baru serta masalah-masalah yang berkaitan seperti masalah sosial dan emosi berkemungkinan mengubah keadaan pembelajaran dan pengajaran pada hari ini.

\section{RUJUKAN}

Abouserie, R. 1994. Sources and Levels of Stress in relation to Locus of Control and Self Esteem in University Students, Educational Psychology, 14 (3), 323-331.

Baumrind, D. 1991. The Influence of Parenting Style on Adolescent Competence. In Child Development Today and Tomorrow. San Franciso: Jossey-Bass. 349-378.

Becker, T.E., Billings, D.M., \& Gilber, N.L. 1996. Foci and Bases of Employee Commitment: Implications for Job Performance. Academy of Management Journal. 39:464-482.

Bidin Yatim, Sharifah Soa'ad, Syed Yahaya, Mohd. Sobri \& Zurni Omar 1995. Kursus Matematik Punca Utama Kegagalan Pelajar. Prosiding Seminar Penyelidikan UUM. Pusat Penyelidikan dan Perundingan, UUM.

Brophy, J. 1985. Interactions of Male and Female Students With Male and Female Teachers. In L Wilkinson \& C. Marret (Eds). Gender Differences In Classroom Interaction, 115-142. Orlando FI: Academic Press.

Brown, J. \& Taylor, R. 1989. Collective Self-Esteem and In Group Bias. Journal of Personality and Social Psychology, 58, 60-67.

Burnett, P.C. 2000. Student' Conceptions of Learning The Classroom Environment and Approaches To Learning, Journal of Educational Research, 16:220-231.

Chickering, A. 1972. Education and Identity. San Francisco: Jossey-Bass.

Darling, N., \& Steinberg, L. 1993. Parenting Style as Context: An Integrative 
Strategi ini bukan sahaja boleh mengelakkan pemberian tugasan akademik yang tidak sesuai dan berkemungkinan membebankan pelajar, tetapi juga boleh memantapkan penyeliaan dan pengajaran sesuatu kursus kerana ia merupakan keperluan rancangan kerja bagi ISO untuk pengajaran dan pembelajaran. Keperluan pengajaran juga harus merangkumi peringkat taksonomi Bloom di mana matriks perancangan kurikulum dan penyediaan bahan penilaian boleh dibina berdasarkan pemberian tugasan dari peringkat yang mudah ke peringkat yang lebih sukar. Tahap kecekapan taksonomi Bloom menyatakan bahawa setiap penilaian harus dimulakan dengan unsur pengetahuan dan dikuti oleh kefahaman, aplikasi, analisis, sintesis dan akhirnya unsur penilaian. Tahap ini juga haruslah berdasarkan peringkat kursus iaitu kursus-kursus peringkat tahun awal pengajian tentunya menggunakan unsur yang lebih rendah berbanding dengan kursus di peringkat tahun dua, tiga atau empat.

Sehubungan itu, Pusat Pengajaran dan Pembelajaran Universiti (UTLC) boleh mengambil inisiatif dengan memasukkan topik yang berkaitan dengan beban tugas yang bersesuaian berdasarkan tahap kursus (tahap 1XXX, 2XXX dan $3 X X X)$ dalam modul-modul latihan mereka atau dalam program pensijilan. Pensyarah-pensyarah harus didedahkan dengan strategi pemberian tugasan akademik yang sesuai. Ini akan membolehkan pensyarah mendapat pendedahan yang lebih luas tentang peranan mereka dalam pemberian tugasan yang sesuai.

Kaedah pengajaran baru perlu diperkenalkan. Antaranya ialah kaedah pengajaan bermodul perlu diperluaskan. Tidak semua kursus mempunyai modul pengajaran yang lengkap. Justeru itu, selain dari sistem kepedulian pembelajaran (learning-care) yang menjadi teras pengajaran, sistem pembelajaran bermodul juga harus mendasari sistem pengajaran dan pembelajaran di universiti.

Pihak universiti dapat membantu para pelajar menangani masalah beban tugas akademik dengan bijak melalui kursus jangka pendek yang menekankan kepada strategi menangani tekanan yang dialami akibat daripada beban tugas akademik setiap semester. Kursus-kursus pengurusan masa yang berteraskan struktur akademik serta merangkumi elemen-elemen pengurusan tekanan boleh diterapkan sebagai sebahagian daripada modul kursus ini. Di samping itu, pelajar-pelajar hendaklah diberikan kursus yang melibatkan pengurusan emosi kerana kawalan emosi dalam menghadapi beban tugas akademik merupakan sesuatu yang amat penting dewasa ini.

\section{KESIMPULAN}

Keseluruhannya kajian ini mendapati sebenarnya pelajar di UUM tidak menghadapi masalah yang serius berdasarkan faktor-faktor yang dikaji. Hanya faktor tekanan akademik dan beban tugas yang dikesan menjadi faktor yang menjadi masalah pelajar berdasarkan skor pelajar dalam kategori tinggi untuk faktor-faktor ini. Bagi faktor-faktor lain, dapatan kajian mendapati tidak ada 
Nouwens, F. 1997. Student Workload. Cited in S.Dixon, G.Lafoe, F.Nouwens and S. Wills (eds). Teaching at a Distance [CD-ROM].Page: Melbourne.

Orenstein, P. 1994. School Girls. New York: Banton Doubleday Dell Publishing Group, Inc.

Okun, M.A. \& Fournett, L.M. 1991. Academic Self-Esteem and Perceived Validity of Grades: A Test of Self-Verification Theory. Contemporary Educational Psychology, 18, 414-426.

Othman Md Johan. 2001. Students Behaviour Problem : An Attempt to Understand the Causes. Jurnal Pendidikan. Universiti Teknologi Malaysia, 7, 75-88.

Ranjita Misra \& Mckean, M. 2000. College Students' Academic Stress and Its Relationship to Their Anxiety, Time Management, and Leisure Satisfaction. American. Journal of Health Studies, 16 (1), 41-51.

Solomon, C. 1998, "Building teams across borders," Global Workforce, 3 (6), pp.62-81.

Suradi Salim. 1984. Adjustment Problems of Malaysian Students At Western Michigan University. Ann Arbor: University Microfilms International.

Trott, D.C. 1996. Spiritual Well-Being of Workers: An Wxploratory Study of Spirituality in the Workplace, Universiti of Texas, Austin, TX.

T.Subahan M. Meerah. 1990. Pembinaan Alat Kajian Untuk Mengukur Tingkahlaku Pengajaran Di Sekolah Dan Universiti. Jurnal Pendidikan.15, 43-63.

Wentzel, K. 1997. Student Motivation in Middle School: The Role of Preceived Pedafosical Caring. Journal of Educational Pschology, 89, 411-417.

Wiggins, J.D. 1987. Self-Esteem, Earned Grades and Television Viewing Habits of Students. The School Counselor, 35 (2), 128-133.

Najib Ahmad Marzuki, Ph.D

Profesor Madya

Fakulti Pembangunan Sosial dan Manusia

06010 Universiti Utara Malaysia

Sintok, Kedah Darul Aman, Malaysia

Che Su Mustaffa, Ph.D

Profesor Madya

Fakulti Komunikasi dan Bahasa Moden

06010 Universiti Utara Malaysia

Sintok, Kedah Darul Aman, Malaysia

Zarina Mat Saad

Fakulti Pembangunan Sosial dan Manusia

06010 Universiti Utara Malaysia

Sintok, Kedah Darul Aman, Malaysia 
Model. Psychological Bulletin, 113 (3), 487-496.

Debra S. S., \& Clifford R. M. 1999. Graduate Students Relationship With Their Male and Female Major Professors. Sex Roles: A Journal of Research, 67-81.

Eccles, J.S. \& Smidfley, C. 1989. Stage Environment Fit. Development Appropriate Classrooms for Young Adolscents. In C. Ames \& R. Ames (eds). Research on Motivation in Education. San Diego: Academic Press.

Hamachek, D. 1995. Self-Concept and School Achievement: Interaction Dynamics and a Tool for Assessing the Self-Concept Component. Journal of Counseling \& Development, 73 (4), 419-425.

Henderson, R.I. 2000. Compensation Management in a Knowledge-Based World. $8^{\text {th }}$ ed. Upper Saddle River: Prentice Hall.

Hite, L.M. 1985. Female Doctoral Students: Their Perceptions and Concerns. Journal of College Student Personnel, 26, 18-22.

Gregersen, H.B 1993. Multiple Commitments at Work and Extra Role Behavior during Three Key Mediating Construct. Academy of Management Journal. 33:568-1587.

Institute for Social Research. 1999. Confidence in Time Management Over Four Years of Study. ISR Bulletin 38. York University: Institute for Social Research.

Jabatan Hal Ehwal Akademik. 2003. Universiti Utara Malaysia.

Kember, D \& Ng, S. 1996. An Examination of the Interrelationships Between Workload, Study Time, Learning Approaches, English Ability and Grade Point Average. Studies in Higher Education, 21. Issue 3, 347.

Krejcie, R. \& Morgan, D. 1970. Determining Research Size for Research Activities. Educational and Psychological Measurement, 30, 607-610.

Macan, T. 1994. Time Management: Test of a Process Model. Journal of Applied Psychology. 79 (3), 381-391.

Marsh, H.W. 1989. Age and Sex Effects In Multiple Dimensions of SelfConcept: Preadolescence to Early Adulthood. Journal of Educational Psychology, 81, 417-430.

McClun, L.A., \& Merrell, K.W. 1998. Relationship of Perceived Parenting Styles, Locus of Control, Orientation, and Self-Concept Among Junior High Age Students. Psychology in the Schools, 35 (4), 381-389.

Michie, F., Glachan, M.\& Bray, D. 2001. An Evaluation of Factors Influencing the Academic Self-Concept, Self-Esteem and Academic Stress for Direct and Re-Entry Students in Higher Education. Educational Psychology, 21 (4), 455-472.

Murdock, T.B. 1999. The Social Context of Risk : Social and Motivational Predictors of Alienation in Middle-School. Journal of Educational Psychology, 91, 1-14.

Murdock, T.B.,Anderman, C.H. \& Hodge, S.H. 2000. Middle-grade Prediators of Students Motivation Behavior in High School. Journal of Adolescent Research, 327-342. 
Suhanim Abdullah

Fakulti Sains Kognitif dan Pendidikan

06010 Universiti Utara Malaysia

Sintok, Kedah Darul Aman, Malaysia 